Article

\title{
Integration of Satellite InSAR with a Wireless Network of Geotechnical Sensors for Slope Monitoring in Urban Areas: The Pariana Landslide Case (Massa, Italy)
}

\author{
Andrea Ciampalini ${ }^{1, *} \mathbb{0}$, Paolo Farina ${ }^{1}\left(\mathbb{D}\right.$, Luca Lombardi ${ }^{2}$, Massimiliano Nocentini ${ }^{2}$, Veronica Taurino ${ }^{1}$, \\ Roberto Guidi ${ }^{3}$, Fernando della Pina ${ }^{4}$ and Davide Tavarini ${ }^{4}$ \\ 1 Geoapp s.r.l., 50121 Florence, Italy; paolo.farina@geoapp.it (P.F.); veronica.taurino@geoapp.it (V.T.) \\ 2 Earth Sciences Department, University of Florence, 50121 Florence, Italy; luca.lombardi@unifi.it (L.L.); \\ massimiliano.nocentini@unifi.it (M.N.) \\ 3 Provincia di Lucca, 55100 Lucca, Italy; r.guidi@provincia.lucca.it \\ 4 Comune di Massa, 54100 Massa, Italy; fernando.dellapina@comune.massa.ms.it (F.d.P.); \\ davide.tavarini@comune.massa.ms.it (D.T.) \\ * Correspondence: andrea.ciampalini@geoapp.it
}

Citation: Ciampalini, A.; Farina, P.; Lombardi, L.; Nocentini, M.; Taurino, V.; Guidi, R.; Pina, F.d.; Tavarini, D. Integration of Satellite InSAR with a Wireless Network of Geotechnical Sensors for Slope Monitoring in Urban Areas: The Pariana Landslide Case (Massa, Italy). Remote Sens. 2021, 13, 2534. https://doi.org/10.3390/ rs13132534

Academic Editors: Cristiano Tolomei and Oriol Monserrat

Received: 3 May 2021

Accepted: 23 June 2021

Published: 29 June 2021

Publisher's Note: MDPI stays neutral with regard to jurisdictional claims in published maps and institutional affiliations.

Copyright: (c) 2021 by the authors. Licensee MDPI, Basel, Switzerland. This article is an open access article distributed under the terms and conditions of the Creative Commons Attribution (CC BY) license (https:/ / creativecommons.org/licenses/by/ $4.0 /)$.

\begin{abstract}
Slow to extremely slow landslides in urban areas may cause severe damage to buildings and infrastructure that can lead to the evacuation of local populations in case of slope accelerations. Monitoring the spatial and temporal evolution of this type of natural hazard represents a major concern for the public authorities in charge of risk management. Pariana, a village with 400 residents located in the Apuan Alps (Massa, Tuscany, Italy), is an example of urban settlement where the population has long been forced to live with considerable slope instability. In the last 30 years, due to the slope movements associated with a slow-moving landslide that has affected a significant portion of the built-up area, several buildings have been damaged, including a school and the provincial road crossing the unstable area, leading to the need for an installation of a slope monitoring system with early warning capabilities, in parallel with the implementation of mitigation works. In this paper, we show how satellite multi-temporal interferometric synthetic aperture radar (MT-InSAR) data can be effectively used when coupled with a wireless sensor network made of several bar extensometers and a borehole inclinometer. In fact, thanks to their wide area coverage and opportunistic nature, satellite InSAR data allow one to clearly identify the spatial distribution of surface movements and their long-term temporal evolution. On the other hand, geotechnical sensors installed on specific elements at risk (e.g., private buildings, retaining walls, etc.), and collected through Wi-Fi dataloggers, provide near real-time data that can be used to identify sudden accelerations in slope movements, subsequently triggering alarms. The integration of those two-monitoring systems has been tested and assessed in Pariana. Results show how a hybrid slope monitoring program based on the two different technologies can be used to effectively monitor slow-moving landslides and to identify sudden accelerations and activate a response plan.
\end{abstract}

Keywords: monitoring system; landslide; geotechnical sensor; InSAR; permanent scatterer interferometry

\section{Introduction}

In Italy, landslides represent a major geological risk involving damage to buildings and infrastructure, and they can often cause the loss of human life [1,2]. Northern Tuscany is one of the areas in Italy with the highest landslide risk due to its lithology, relief, and structural and meteorologic characteristics. The most recent destructive event occurred in 1996, when $478 \mathrm{~mm}$ of rain fell in $13 \mathrm{~h}$ in this region, killing 13 people and resulting in one missing person and the damage of around 4000 private houses $[3,4]$. Most of the causes of landslides in northern Tuscany are related to fast slope movements and the prevalent flow of debris [5,6]. On the other hand, slow (up to $13 \mathrm{~m} / \mathrm{month}$ ) to extremely 
slow $(<13 \mathrm{~mm} / \mathrm{y})$ landslides [7] are less dangerous in terms of casualties, but they usually cause serious damage to buildings and infrastructure [8]. These kinds of landslide are widespread in northern Tuscany and they affect several urban settlements scattered within hilly and mountainous areas [9-11]. Most of these slow to extremely slow landslides do not provoke particular concern, but some of them reach deformation rates, causing severe damage to buildings [11]. One of these landslides has affected Pariana (Massa, Tuscany, Italy), a small hamlet where about 400 people live. In recent years, several fractures have developed on the façade of some private houses, leading to the need to install a near real-time monitoring system with early warning capabilities. Near-real-time, real-time, or early warning monitoring systems are useful tools for monitoring the evolution of the deformations and for retrieving information about landslide dynamics. These systems are of fundamental importance when a landslide involves elements of risk.

Today, several instruments, sensors, and techniques to monitor ground deformations over time are available. These instruments range from direct contact geotechnical sensors, installed on the landslide and passing through terrestrial remote sensing technologies, to observations from space. For example, inclinometers [12,13], GPS [14], strain gauges [15], and topographic levelling [16] are usually installed or performed directly on the landslide area. Terrestrial laser scanning $[17,18]$ and ground-based radar interferometry [19-22] can measure ground deformations from a certain distance from the landslide. Increasing the distance between the landslide and the sensor, UAV (Unmanned Aerial Vehicle) photogrammetry $[23,24]$ can be used. An advantage of most of these sensors relies on their frequent acquisition of measurements, which can also be continuous in case of an early warning system [25]. Another advantage is that data acquisition of several sensors placed in different positions on the unstable slope can be organized through the installation of wireless dataloggers that are capable of transferring data to a central gateway equipped with a UMTS/4G modem; these data are then transferred to a server and made accessible through a web platform in near real-time [26,27].

Spaceborne remote sensing techniques can be also used to measure ground displacements induced by a landslide. When dealing with a slow to extremely slow-moving landslide, synthetic aperture radar (SAR) data have been extremely useful since the 1990s [28-30]. Multi-temporal interferometric synthetic aperture radar (MT-InSAR) techniques developed in recent decades exploit space-acquired SAR images to measure ground deformation with accuracy of up to a millimeter [31]. From the 2014, and with the launch of the Sentinel-1 mission, the regular acquisition of free-of-charge SAR images over Europe allowed the use of such a spaceborne techniques in order to measure ground motion; measurements are routinely updated each time a new Sentinel 1 image becomes available.

Such a service has been available in Tuscany (Central Italy) since 2015, thanks to a research program funded by Regione Toscana. MT-InSAR data acquired from 2015 and updated every six days are made available over a webgis platform [32].

In this work, we show how data obtained from spaceborne MT-InSAR data can be effectively used for landslide monitoring when coupled with a wireless network of geotechnical sensors. The integration between these two-monitoring systems has been tested and evaluated in the village of Pariana (Massa, Italy). The usefulness of the proposed monitoring system can be improved by integrating it with analytical methods to perform a prediction of the mobility of rainfall-induced landslides [33-35].

\section{Study Area}

The study area is located in the northern-western part of the Tuscany region (central Italy), along the western flank of the Apuan Alps (northern Apennines, Figure 1). The urban settlement of Pariana is part of the municipality of Massa and is located at an elevation of around $500 \mathrm{~m}$ a.s.l. The study area is classified as Csa following the Köppen-Geiger classification [36]. The mean annual temperature is $14.7^{\circ} \mathrm{C}$ and the rainfall annual average is about $970 \mathrm{~mm}$, with two wet seasons (spring and autumn). 


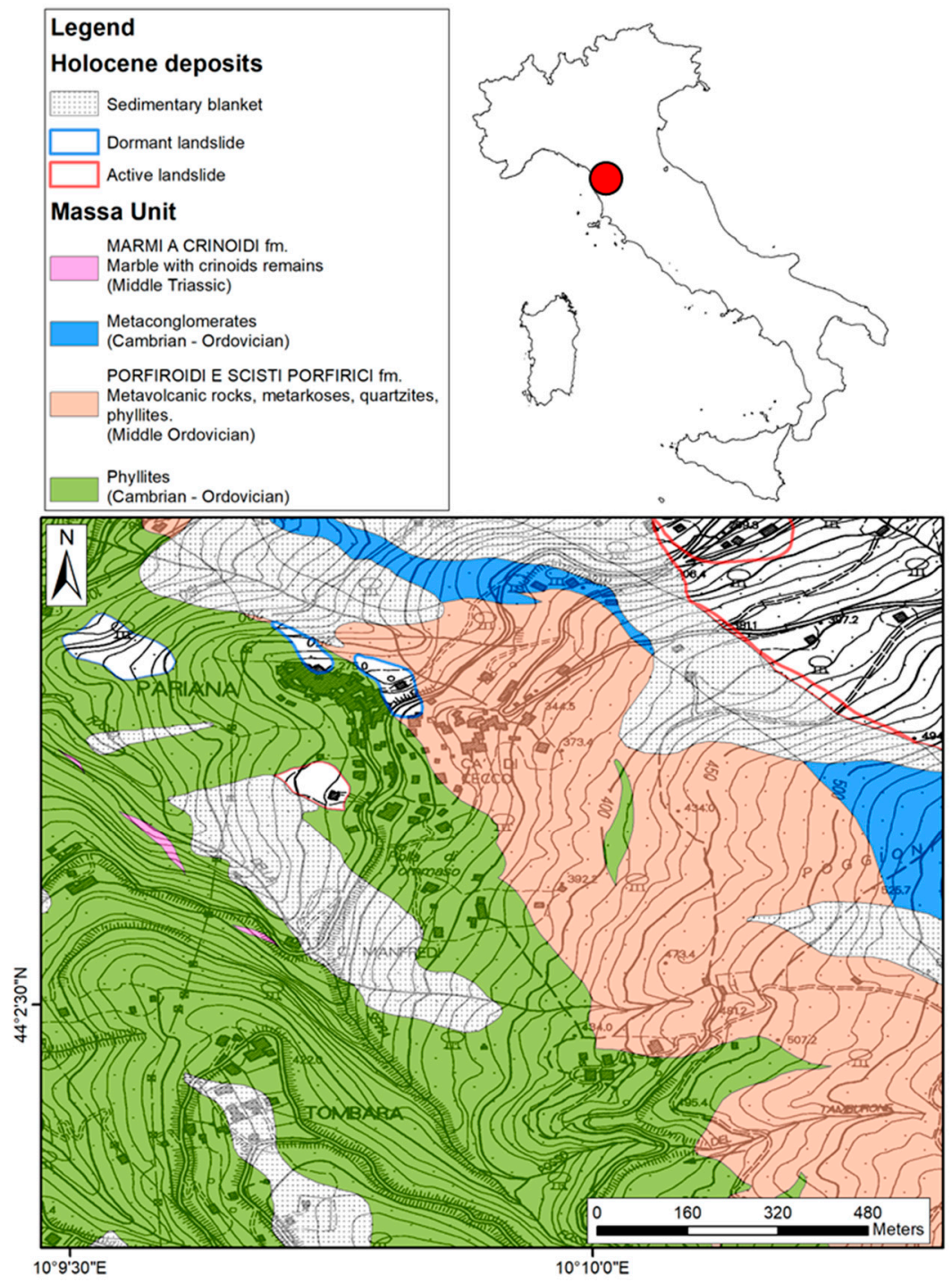

Figure 1. Location and geological map of the study area.

The study area is located along the western side of the Apuan Alps, which represents one of the most important tectonic windows in the inner northern Apennines. The Apuan Alps are a metamorphic complex $[37,38]$ made of two principal metamorphic units which, from the structural top to the bottom, are the Apuan Unit and the Massa Unit [39]. These major units are overlayed by the Tuscan Nappe, the Canetolo Unit, and the Liguride Unit, all of which are characterized by very low-grade metamorphism [40].

The hamlet of Pariana is entirely located in an area characterized by the presence of the Massa Unit (Figure 1). The rocks belonging to the Massa unit are characterized by two main poly-phase tectono-metamorphic events [38]. Pariana lies on two different lithologies belonging to the Massa Unit: the Porfiroidi and scisti porfirici formation made of metavolcanic rocks (metarkoses, quartzites, and phlyllites) to the E-NE, and the Phyllites formation (phyllites, phyllites rich in quartz, and quartzites) to the W-SW.

A borehole located in the southern part of the hamlet, in correspondence with the Phyllites formation, highlights the presence of anthropic material between the ground's surface and $2.5 \mathrm{~m}$ below, followed by sandy silt and silt with fragments of phyllites between 2.5 and $28 \mathrm{~m}$ below the ground's surface. This thickness represents an alteration in the Phyllites' formation, which can be found from $28 \mathrm{~m}$ below the surface.

The Apuan Alps are historically affected by landslides because of their peculiar geomorphological setting. This metamorphic complex forms a coastal range with an elevation 
up to $1945 \mathrm{~m}$ a.s.l. and a high average slope gradient. Landslides are commonly triggered by rainfall events (the Apuan Alps is one of the rainiest areas in Italy, with maximum values around $3.300 \mathrm{~mm} / \mathrm{y}$ at the upper elevations) but also by seismic events [41].

The landslide involving the hamlet of Pariana is a historical, deep-seated landslide. The last reactivation occurred in October 2010. Today, the active landslide affects the southern part of the hamlet by damaging several buildings, including private houses and a former school.

\section{Materials and Methods}

\subsection{InSAR Data}

MT-InSAR is a remote sensing technique based on the processing of a stack of synthetic aperture radar [42]. Ground deformation can be measured over long period by exploiting phase information [31]. Deformation measurements can be made in correspondence with point-wise targets that are characterized by stable radiometric behavior over time, i.e., the so-called persistent scatterers (PS), which are represented by natural (e.g., rocky outcrops) or human-made (buildings, infrastructures) structures [42]. The density of PS is directly related to the presence of highly reflective targets on the ground; for this reason, urbanized areas are excellent targets that can be monitored with the persistent scatterer interferometry (PSI) technique [43-45]. The measurement of the ground deformation occurs along the satellite line of sight (LOS), and it is characterized by an angle with the Earth's surface.

Among the MT-InSAR processing chains, the SqueeSAR technique allows one to increase the point measurements' density by exploiting both PS and the distributed scatterer (DS, homogeneous areas spread over a group of pixels in a SAR image). Usually, DS corresponds to shrubs, rangeland, or bare land [46]. For each PS or DS, a measurement of the displacement rate $(\mathrm{mm} / \mathrm{yr})$ along the LOS and time series of the deformation in the acquisition period are available. The measurements refer to a reference point that is assumed to not be affected by deformation.

MT-InSAR data were used to evaluate the deformation that occurred in the past (from 1992). In particular, C-band ERS 1/2, Envisat, and X-band COSMO-SkyMed data were analyzed with the intention of identifying the best location for the installation of the in situ sensors.

For the historical analysis, we used ERS 1/2, Envisat, and COSMO-SkyMed data obtained from the National Cartographic Portal (2019) (http: / / www.pcn.minambiente.it/viewer / (accessed on 7 January 2021)) of the Pst-A Project (Piano Straordinario di Telerilevamento, [47]).

On the other hand, Sentinel-1 data, processed with the SqueeSAR technique and obtained within the project "Monitoring ground deformation in the Tuscany Region with satellite radar data", which was funded by Regione Toscana (https:/ / geoportale.lamma. rete.toscana.it/difesa_suolo/\#/viewer/openlayers/326 (accessed on 7 January 2021)), were used to monitor the on-going deformations during the period covered by the in situ monitoring program.

The ground motion operational service of Regione Toscana for the geo-hydrological risk mitigation can be exploited as a support for local landslide monitoring systems, as it it relies on the systematic processing of Sentinel-1 images to create continuously updated ground deformation data $[10,11,32]$. Such a service has been configured to update the deformations map and the displacement time series of all measurement points of the whole regional territory at every new Sentinel-1 image. In the beginning (in 2016), the project relied on Sentinel-1A images only; thus, the update frequency of the displacement measurements was 12 days. However, from January 2017, the time for updates was reduced to 6 days thanks to the launch of Sentinel-1B.

The MT-InSAR dataset used for the characterization and monitoring of the Pariana landslide is reported in Table 1. 
Table 1. PSI dataset used for the characterization and monitoring of the Pariana landslide.

\begin{tabular}{|c|c|c|c|c|c|}
\hline Satellite & Geometry & Acquisition Period & $\begin{array}{c}\text { Velocity } \\
\text { Standard Deviation }(\mathrm{mm} / \mathrm{y})\end{array}$ & $\begin{array}{l}\text { Incident } \\
\text { Angle }\left(^{\circ}\right)\end{array}$ & $\begin{array}{c}\text { Ground } \\
\text { Resolution }\end{array}$ \\
\hline ERS $1 / 2$ & Descending & $\begin{array}{l}06 / 07 / 1992- \\
30 / 11 / 2000\end{array}$ & \pm 1.1 & 23 & $26 \times 30$ \\
\hline Envisat & Descending & $\begin{array}{l}25 / 12 / 2003- \\
01 / 07 / 2010\end{array}$ & \pm 0.65 & $15-45$ & $28 \times 28$ \\
\hline COSMO-Skymed & Descending & $\begin{array}{l}26 / 04 / 2011- \\
02 / 04 / 2014\end{array}$ & \pm 1.5 & $22-37$ & $3 \times 3$ \\
\hline Sentinel-1 & Descending & $\begin{array}{l}22 / 03 / 2015- \\
14 / 11 / 2020\end{array}$ & \pm 1.5 & $29-46$ & $14 \times 5$ \\
\hline Sentinel-1 & Ascending & $\begin{array}{l}23 / 03 / 2015- \\
15 / 11 / 2020\end{array}$ & \pm 0.6 & $29-46$ & $14 \times 5$ \\
\hline
\end{tabular}

\subsection{Geotechnical Monitoring Network}

Wireless sensor networks (WSN) are made of networks of devices (nodes) which exploit a wireless network to communicate acquired information from local sensors. The main advantage of a WSN is represented by its capability to quickly measure and transmit data in near real-time, acting as a real-time monitoring system or, in some cases, as an early warning system $[26,27,48]$. WSN can be connected to different types of devices, including geotechnical sensors.

The monitoring system installed in the hamlet of Pariana consists of a network of geotechnical sensors formed by a wireless data transmission and reception coordinator node equipped with a UMTS module, and by a series of wireless router nodes that transmit data to the coordinator (Figure 2). Each node is connected by cable to a certain number of geotechnical sensors. The coordinator node receives and sends sensor data to a specific web platform. The geotechnical sensors installed on the Pariana landslide that are connected to the nodes are both superficial (bar extensometers/strain gauge) and borehole (wire extensometers). The entire monitoring network constitutes a self-reconfigurable WSN that is able to compensate for any deficiencies in some nodes in the transmission of sensor data to the coordinator node. The sensors are battery powered and can be recharged by solar panels.
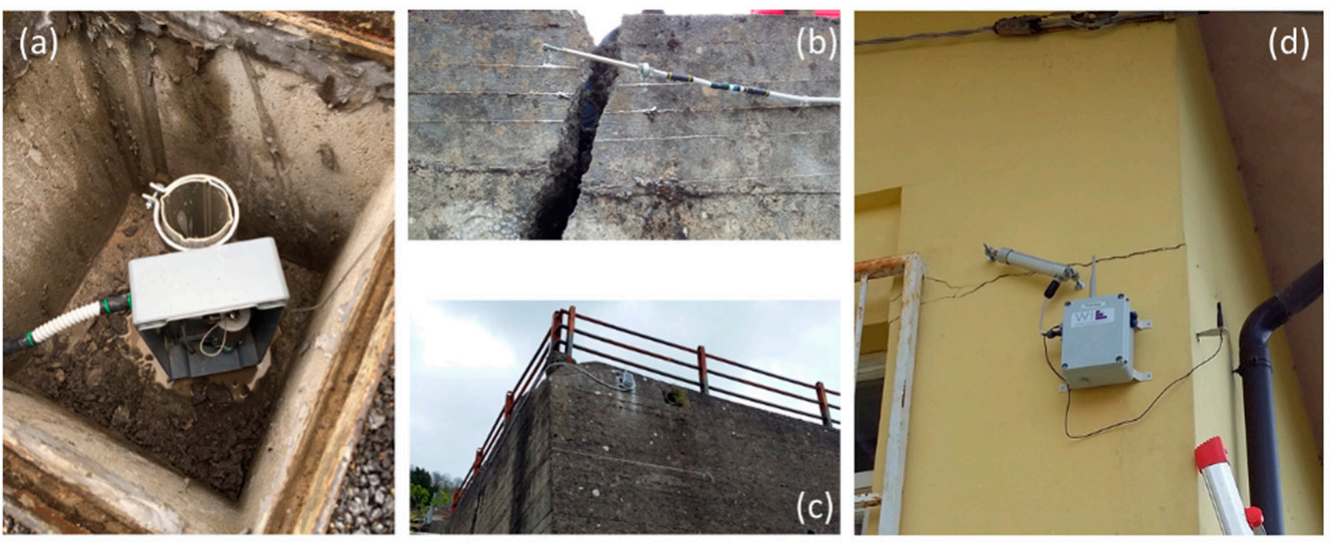

Figure 2. Some examples of sensors included in the WSN monitoring system: (a) a wire extensometer coupled with an inclinometer; $(\mathbf{b}, \mathbf{c})$ a bar extensometer with the related node (E3); (d) another bar extensometer with its node mounted on the façade of the school (E4).

The devices have been installed on damaged buildings and in a borehole to collect data at regular time intervals. Before the installation of the monitoring system, an assessment of the most critical areas in terms of damaged buildings was performed to plan the most useful installation of monitoring sensors. The most critical areas on which to install the 8 monitoring sensors were identified soon after the first field survey. Archival InSAR data were analyzed to identify the areas most affected by ground deformations. 
The devices used in this case are represented by 7 bar extensometers that were installed in April 2016 on building walls; one wire extensometer was installed within a borehole $30 \mathrm{~m}$ deep (Figure 3). Those sensors continuously and automatically record deformations, and give pointwise and one-dimensional information [15,49]. In detail, an extensometer records the displacement between a point located in a stable area and a moving point; this latter point can be located on the ground's surface, on a building wall, or within a borehole. Wire or bar extensometers are commonly used in landslide monitoring due to their low cost.

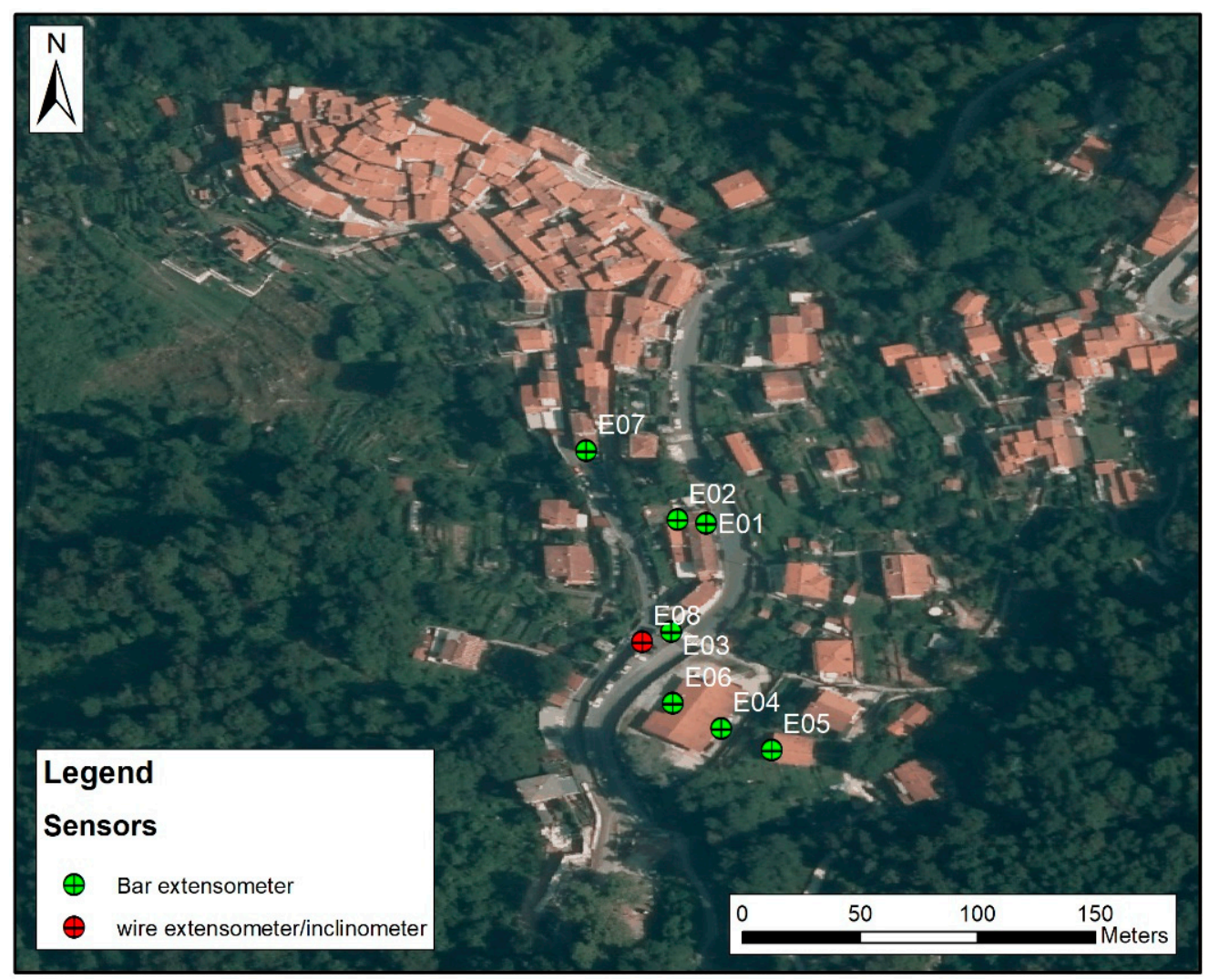

Figure 3. Location of the in situ sensors included in the monitoring system.

The borehole used to install the wire extensometer has been also equipped with an inclinometer casing for manual readings with an inclinometric probe. This instrument is used to measure horizontal displacements at different depths along the borehole [12,50].

Following an initial period, was necessary to calibrate the system (a couple of months). As such, alarms were set based on the deformations measured by the installed sensors. Two alarm levels were set, in agreement with the technicians of the Municipality of Massa: a first level at $1 \mathrm{~mm} /$ day of velocity and a second level at $2 \mathrm{~mm} /$ day. These thresholds were not reached, except for some periods in which some sensors malfunctioned.

Measurements acquired by extensometers and by the manual inclinometer in the period between 04/07/2016 and 15/11/2020 were analyzed.

\subsection{Integration}

Measurements acquired through the wireless sensor network were compared to the time series of deformations of the closest PS/DS to each sensor. The correlation was evaluated using Pearson's coefficients ( $r$ ) and root squared mean error (RSME) values for the PS time series. The deformations measured by the extensometers were compared to rainfall data of the Canevara Station (located a few $\mathrm{km}$ from Pariana) to investigate the influence of rainfall on the deformation trend. 


\section{Results}

The borehole procedure performed to install the inclinometer highlights that the landslide body (around $27 \mathrm{~m}$ ) is prevalently made of an alternation of plastic clayey-sandy silt and clayey silt, with angular clast of phyllites with a maximum dimension of $4 \mathrm{~cm}$. The landslide body is cover by $2 \mathrm{~m}$ of landfill material and the bedrock is made of weathered phyllites (Figure 4). The geotechnical analyses performed on a sample located at a depth of $15 \mathrm{~m}$ highlight that the clayey-sandy silt is characterized by a water content $\left(\mathrm{W}_{\mathrm{N}} \%\right)$ of 13.8 , a unit weight of 2.63 (absolute value), a porosity of $42.1 \%$, a degree of saturation ( $\mathrm{Sr}$ ) of $49.8 \%$, and a specific weight of the whole sample of $17.4 \mathrm{kN} / \mathrm{m}^{3}$; in a drained condition the weight of the whole sample is $14.9 \mathrm{kN} / \mathrm{m}^{3}$ while, in an undrained condition, its weight is $19.1 \mathrm{kN} / \mathrm{m}^{3}$.

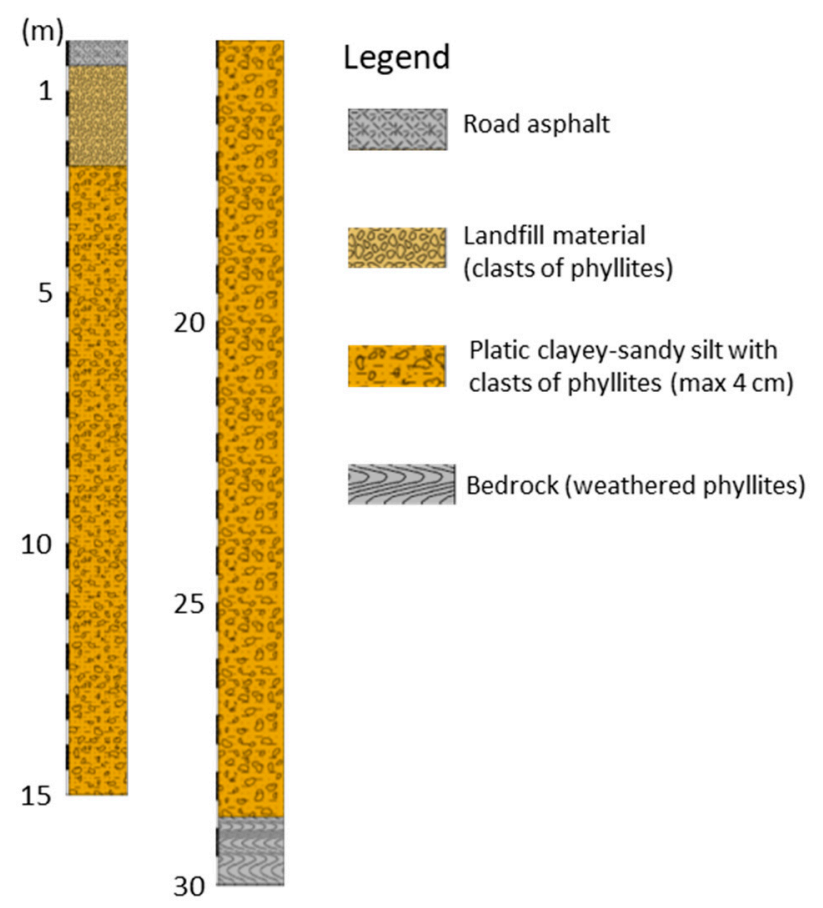

Figure 4. Stratigraphy of the landslide of Pariana deduced by the borehole.

Historical MT-InSAR datasets (ERS, Envisat, and COSMO-SkyMed) covering the time interval from 1992 to 2014 (Figure 5) highlight the presence of ground deformations which affect the village of Pariana in an area located outside the landslide boundaries included in the most recent available landslide inventory. These deformations occurred along the westfacing slope of the relief on which Pariana is located. Considering the orientation of the slope, the deformation data are consistent with the occurrence of gravitational movements with a main westward component, and they can be detected with more accuracy by the descending acquisition geometry.

Considering the past MT-InSAR datasets, it is evident that the south-western side of the village of Pariana is affected by ground deformations whose average velocity increased between 1992 and 2014, growing from a maximum deformation rate of $12.5 \mathrm{~mm} / \mathrm{y}$ and an average deformation rate of $5.18 \mathrm{~mm} / \mathrm{y}$ (ERS) to a maximum deformation rate of $20.3 \mathrm{~mm} / \mathrm{y}$ and an average deformation rate of $6.4 \mathrm{~mm} / \mathrm{y}(\mathrm{CSK})$. The higher deformation rates were measured in the SW part of the village, where the in situ geotechnical sensors were installed in 2016.

The geotechnical monitoring data related to the period between the installation of the sensor network and the end of July 2019 were analyzed. The displacement data were also compared with the daily rainfall values, recorded by the weather station of Canevara (MS), located about $1.5 \mathrm{~km}$ from Pariana, at an altitude of $105 \mathrm{~m}$ a.s.1. (Figures 6 and 7). 

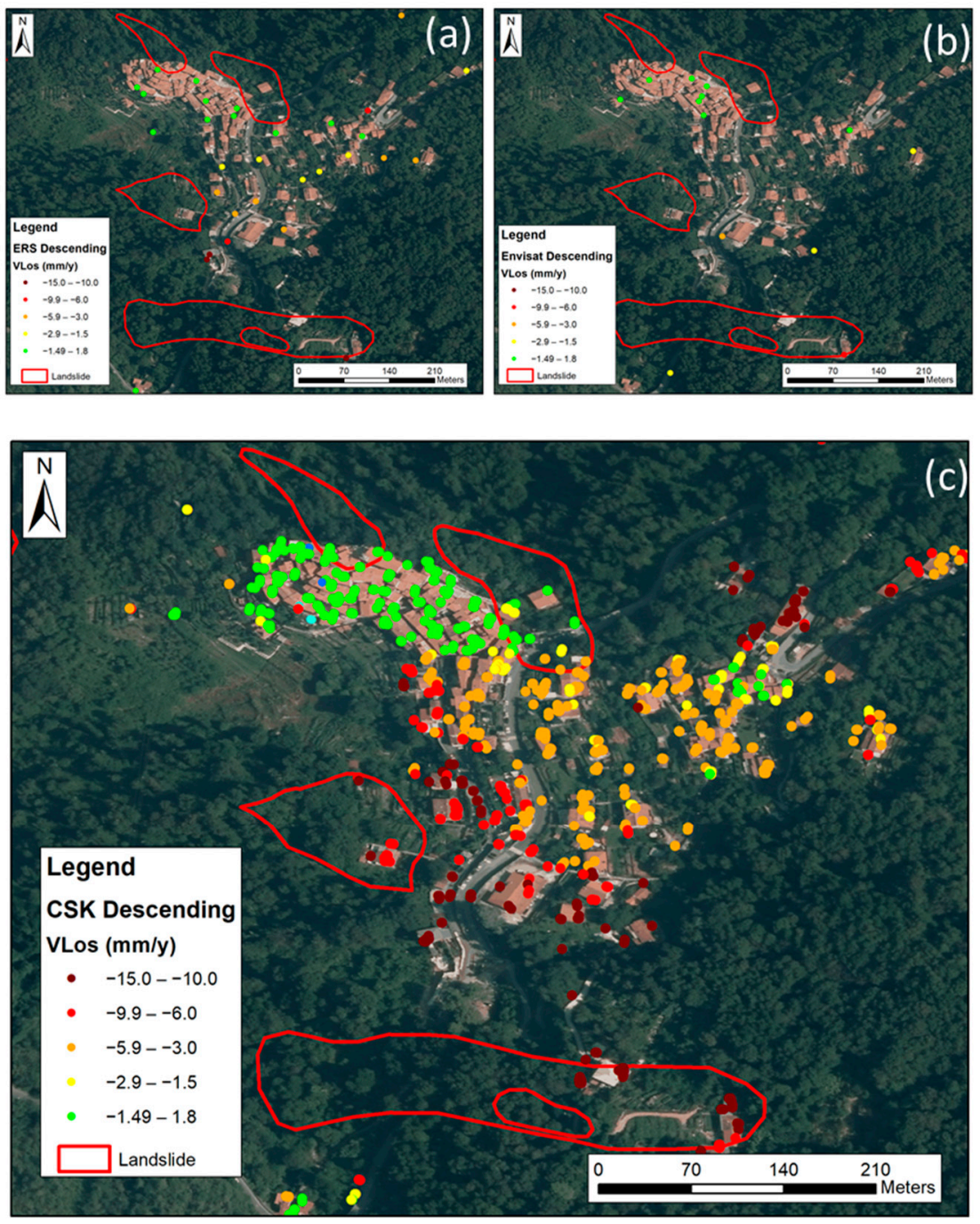

Figure 5. Ground LOS deformation velocity maps of the village of Pariana: (a) ERS descending (1992-2000); (b) Envisat descending (2003-2010) and (c) COSMO-SkyMed descending (2010-2014). Red polygons correspond to landslides mapped in the Landslide inventory map of the Tuscany region.

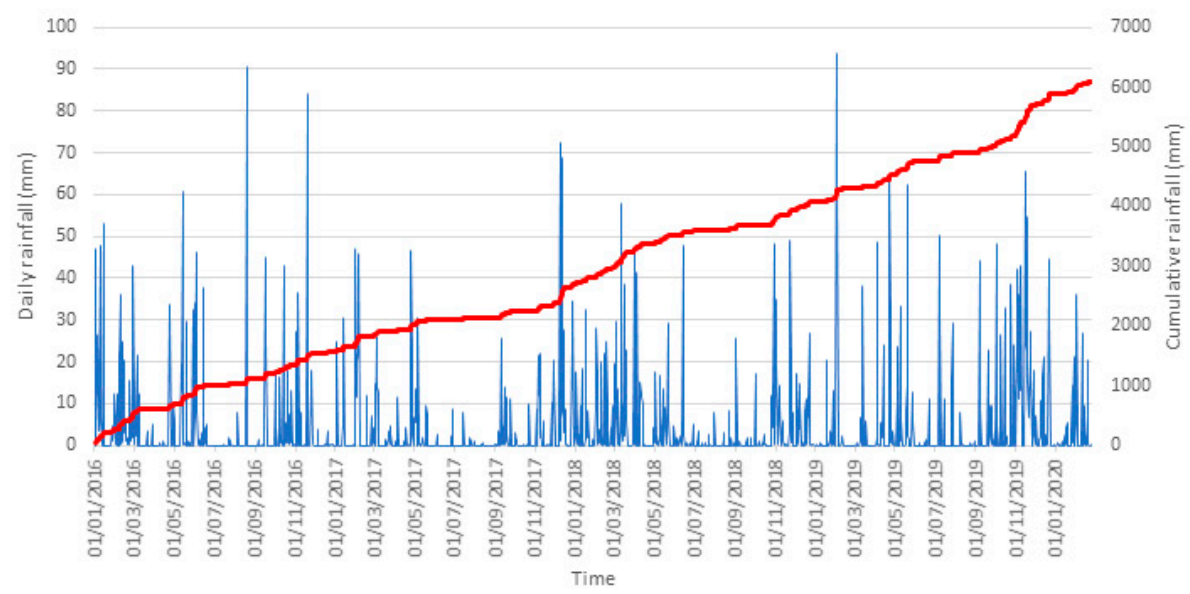

Figure 6. Daily and cumulative rainfall of the Canevara Station. 


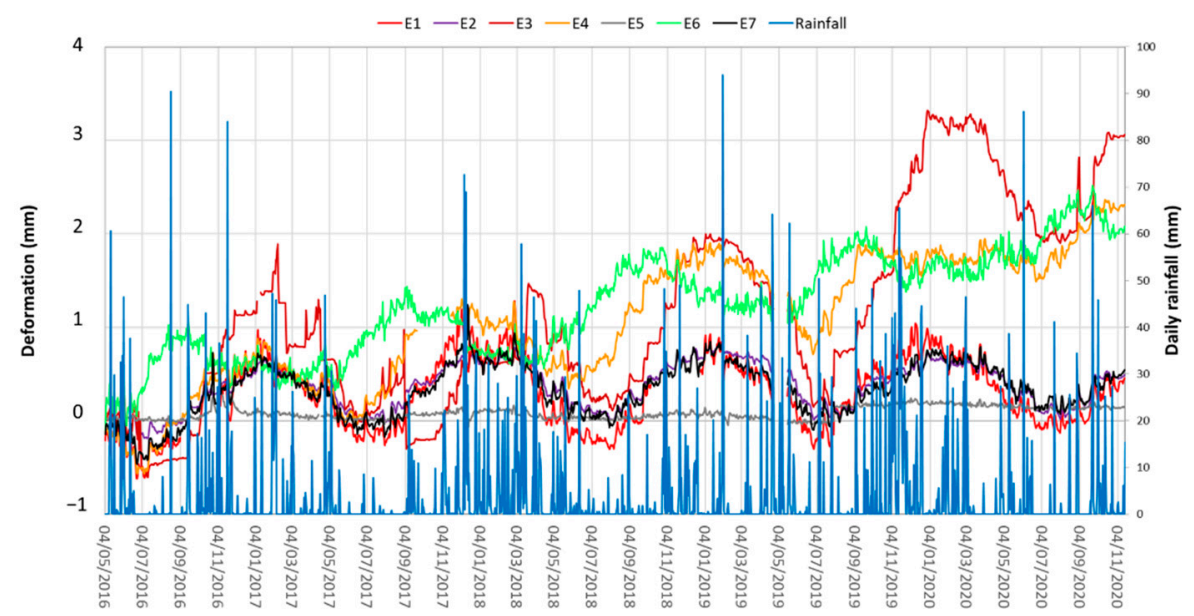

Figure 7. Daily absolute displacement measured by all the sensors of the monitoring system and their comparison with daily rainfall.

The daily displacements recorded by the 7 bar extensometers in the reference period can be observed in Figure 7. All instruments recorded daily and seasonal fluctuations in the deformation measurements related to the thermal variations and the associated dilation/contraction of the electromechanical sensor. Barring the E4 and E6 sensors, installed in correspondence with the former school of Pariana, all instruments only show a seasonal trend, with an increase in the deformation values in the periods between September and February of each year, followed by a decrease between March and August.

Although affected by the same seasonal oscillations as the other sensors, the deformation time series recorded by E4 and E6 also show a slow long-term deformation trend, reaching a maximum cumulative deformation of around $2 \mathrm{~mm}$.

The wire extensometer installed in the borehole (E3) at the beginning of August 2017 shows a slight linear elongation trend, reaching cumulative displacement values of about $15 \mathrm{~mm}$ at $31 / 07 / 2019$.

Figures 7 and 8 show also that the correlation between measured deformations and rainfall is quite evident for most of the sensors. There is a general increase in deformations during the wettest periods of the year.

A summary of the deformations measured by the different sensors is reported in Table 2.

In general, the most important deformations within the monitored area have been detected in correspondence with the area around the former school (sensors E4 and E6). All sensors show seasonality, with an increase in daily deformations during autumn and winter, and a decrease during the spring and summer months (Figure 8). For the two sensors showing clear indication of movements in addition to the thermal variations (E4 and E6), there is a good correlation between displacement and rainfalls, with an increase in deformations in rainy periods and a decrease in the periods of the year less affected by rainfall events (Figure 8).

Figure 9 shows the inclinometer measurements that have been collected manually since 2017. The inclinometric data manually collected in the same period clearly identified a sliding surface at a depth of $23 \mathrm{~m}$, with maximum displacement up to $20 \mathrm{~mm}$ in 2017-2020 and a secondary sliding surface at a depth of $5 \mathrm{~m}$ from ground level, resulting in a total cumulated displacement at the surface of around $36 \mathrm{~mm}$ in the same period. Most of the movements were measured in the first 6 months of 2018, and from 2019 and 2020. 
E3

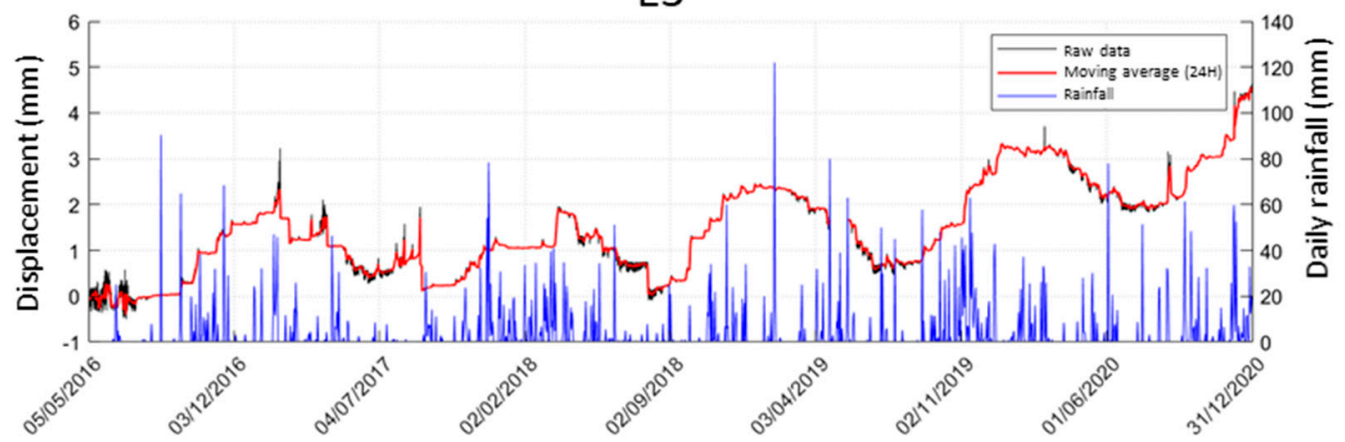

E4

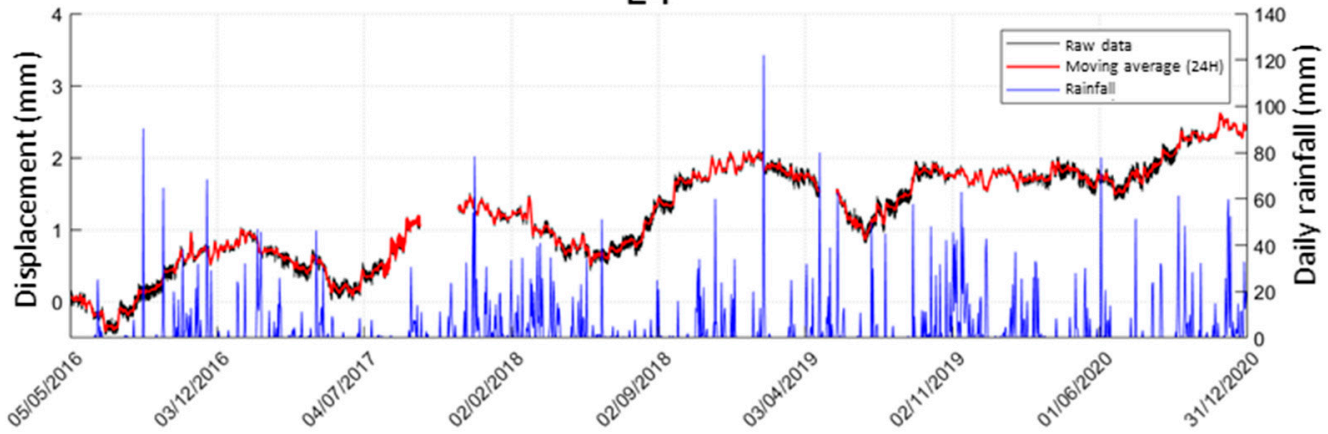

E6

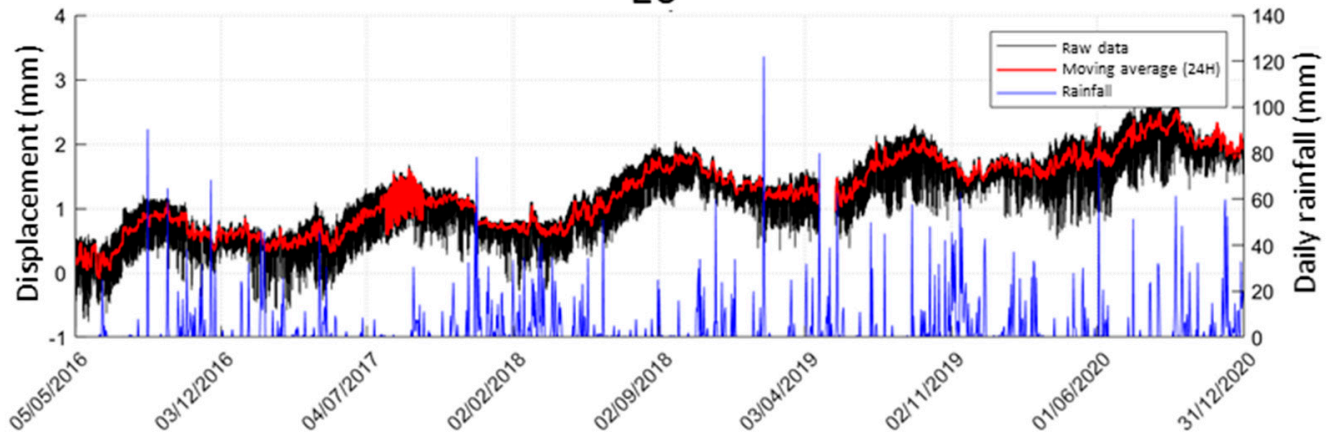

Figure 8. Cumulative deformations measured by extensometers E3, E4, and E6 of the monitoring system and their comparison with daily rainfall.

Table 2. Minimum, maximum, and average daily deformations measured by the sensors of the monitoring system.

\begin{tabular}{|c|c|c|c|c|c|}
\hline \multirow{2}{*}{$\frac{\text { Sensor }}{\text { E1 }}$} & \multicolumn{2}{|c|}{ Daily Minimum (mm) and Date } & \multicolumn{2}{|c|}{ Daily Maximum (mm) and Date } & \multirow{2}{*}{$\frac{\text { Daily Average def. (mm) }}{0.20}$} \\
\hline & -0.62 & $24 / 06 / 2016$ & 1.28 & $22 / 02 / 2018$ & \\
\hline E2 & -0.19 & $12 / 07 / 2016$ & 0.81 & $31 / 01 / 2019$ & 0.30 \\
\hline E3 & -0.61 & $12 / 07 / 2016$ & 2.00 & $12 / 01 / 2019$ & 0.59 \\
\hline $\mathrm{E} 4$ & -0.57 & $25 / 07 / 2016$ & 1.91 & $12 / 01 / 2019$ & 0.75 \\
\hline E5 & -0.07 & $15 / 12 / 2017$ & 0.57 & $06 / 11 / 2016$ & 0.05 \\
\hline E6 & -0.10 & $05 / 04 / 2016$ & 1.96 & $28 / 07 / 2019$ & 0.97 \\
\hline E7 & -0.47 & $25 / 06 / 2016$ & 1.94 & $14 / 12 / 2017$ & 0.30 \\
\hline I1 & -0.26 & $11 / 07 / 2017$ & 2.26 & $12 / 01 / 2019$ & 0.82 \\
\hline
\end{tabular}




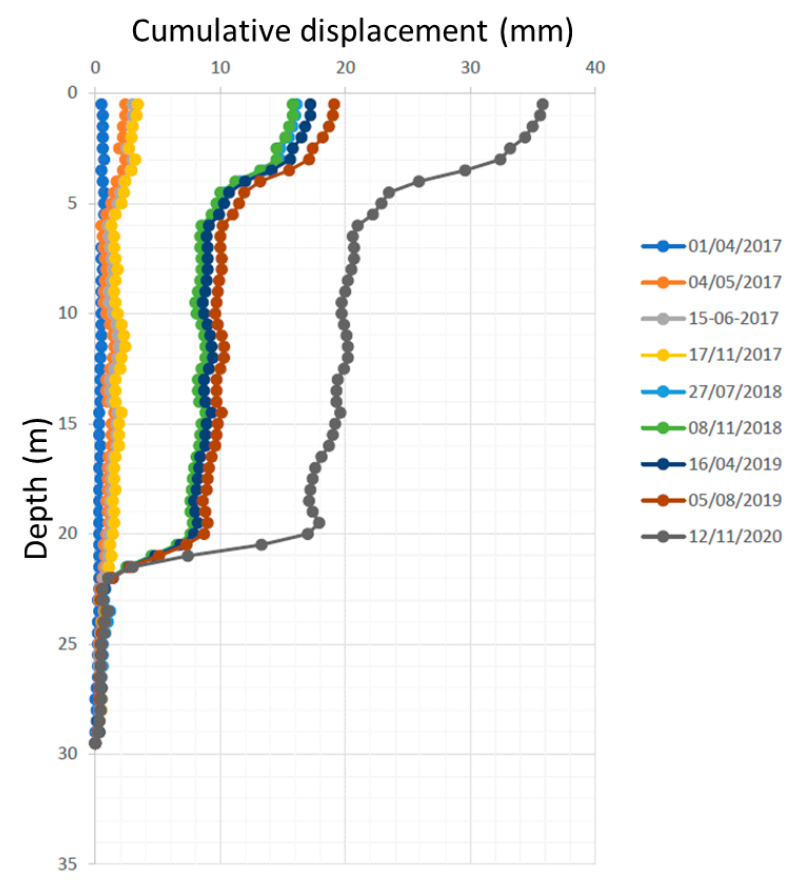

Figure 9. Inclinometer measurements.

\section{Discussion}

The comparison between measurements obtained through the wireless sensor network and MT-InSAR data has been performed by exploiting Sentinel-1 SqueeSAR data, both in ascending and descending orbits (Figure 10).
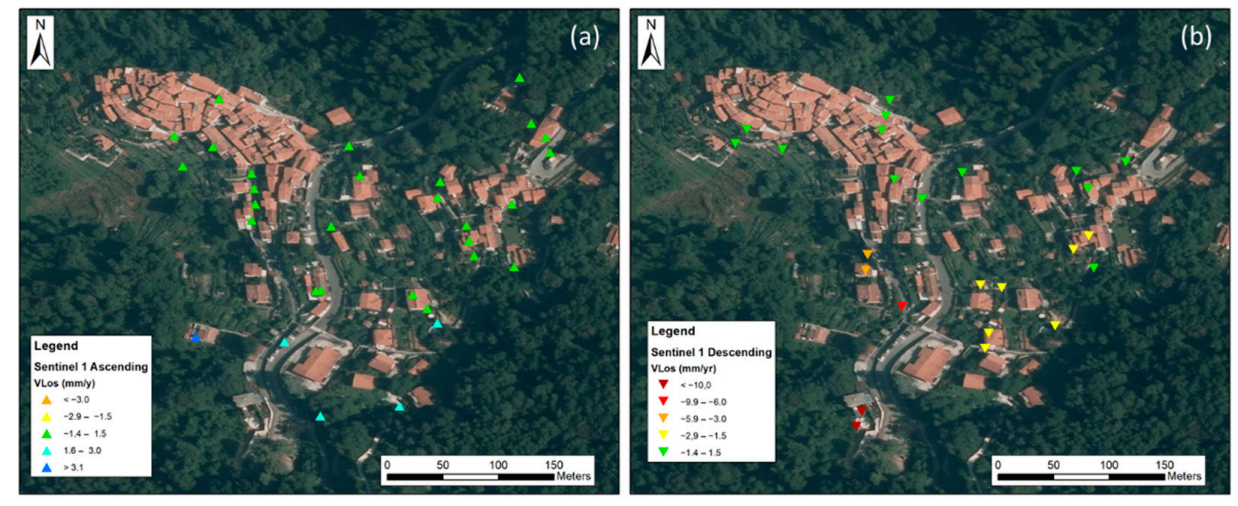

Figure 10. Ground LOS deformation velocity maps of the village of Pariana: (a) Sentinel 1 ascending; (b) Sentinel 1 descending.

Considering the geometry of the slope affected by the landslide, the LOS of the radar sensor in ascending orbit is not optimal with respect to the direction of the movement. The ascending dataset can, in fact, underestimate the horizontal component of the movements due to its inclination. For this reason, PS located in the area affected by ground deformations show average velocity within the stability range $( \pm 1.5 \mathrm{~mm} / \mathrm{y})$. Despite the low velocity measured by the ascending dataset, the displacement time series shows an evident positive deformation trend (approaching the radar sensor), which is a direction compatible with movements with a significant horizontal component towards the south-west (Figure 11a). On the contrary, the LOS of radar sensors along the descending orbit is more suitable when considering the direction of the movement, allowing for a more reliable measurement of real displacement. In this case, the displacements recorded by the PS are characterized by negative values (away from the radar sensor, Figure 11b). 


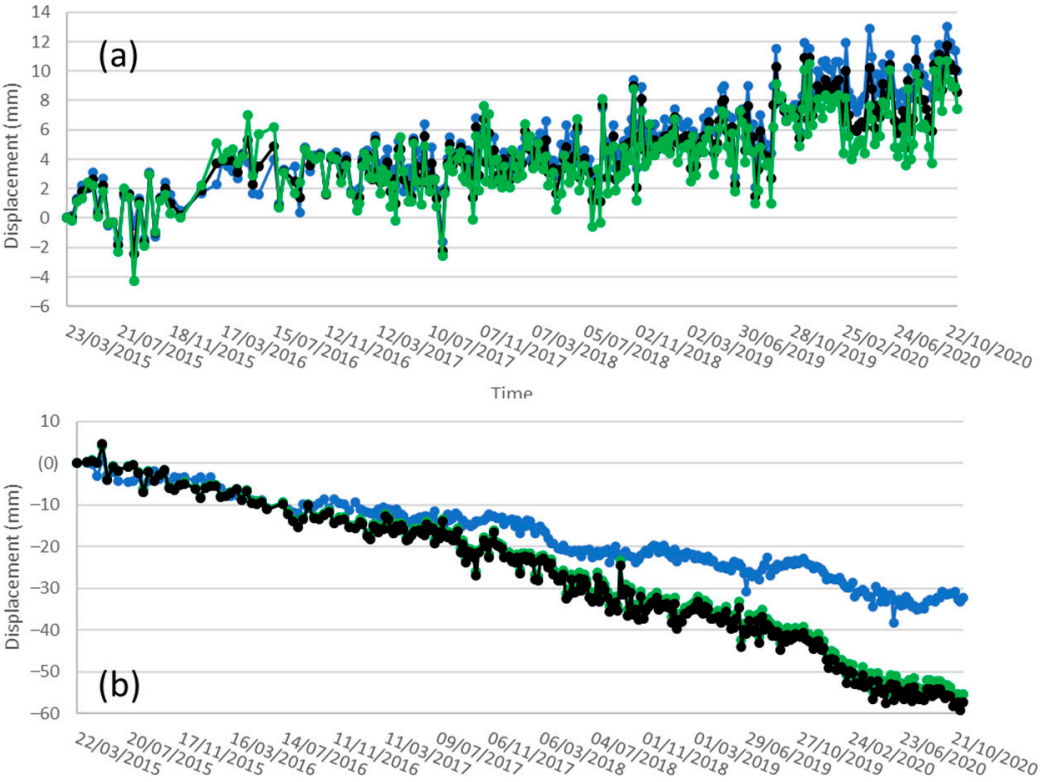

Time

Figure 11. Example of some time series located inside the landslide area: (a) ascending dataset; (b) descending dataset.

MT-InSAR data were compared with the deformations recorded by the instruments of the wireless sensor network. From a spatial point of view, it is worth noting the agreement between the distribution of the faster moving PS/DS of Sentinel 1 descending data and moving points recorded by the wireless sensor network (Figure 12), whereas extensometers characterized by stability are surrounded by stable or extremely slow-moving PS/DS.

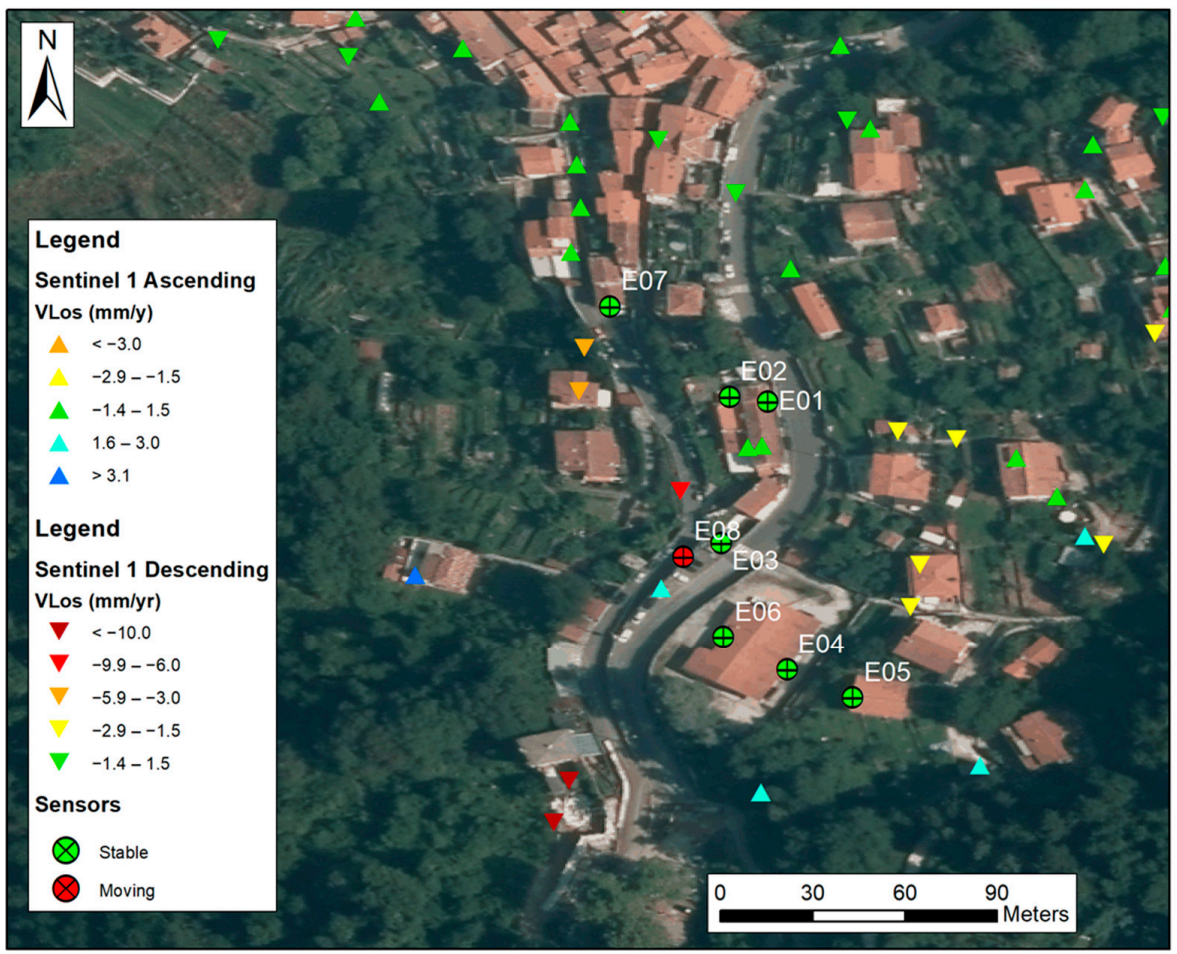

Figure 12. Spatial comparison between MT-InSAR Sentinel 1 data and deformation measured by the wireless sensor network. Colored circles correspond to selected time series for the comparison with extensometer data of Figure 12: black: E1; orange: E3; blue: E6; red: E4. 
Figure 13 shows a comparison between the cumulative deformations measured by 4 bar extensometers and the time series of Sentinel-1 PS in descending orbit, located close to the geotechnical sensors. Both the PS and the extensometers located in the southernmost portion of the hamlet record greater cumulative displacements compared to those located further north.

E1

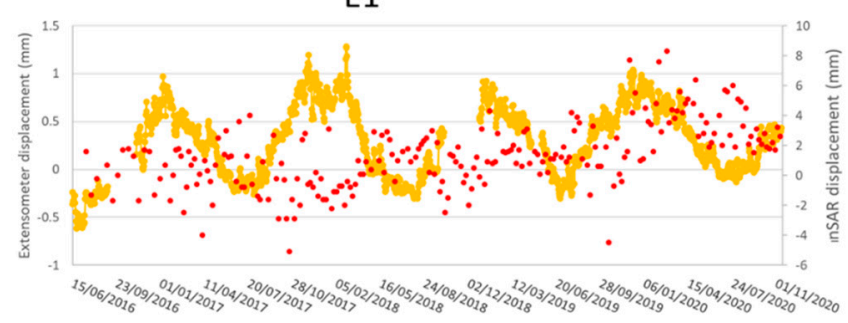

E4

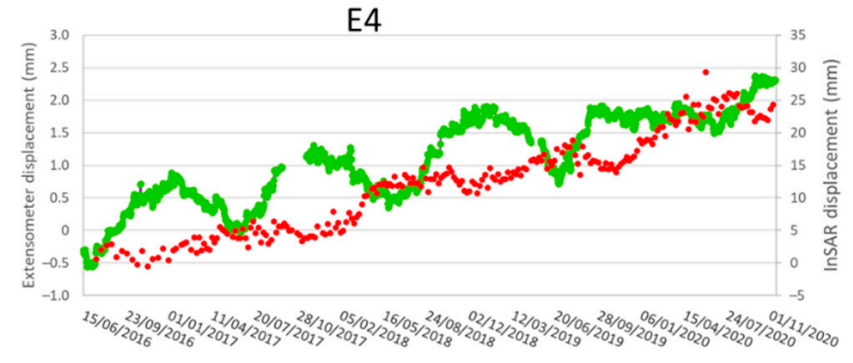

E3

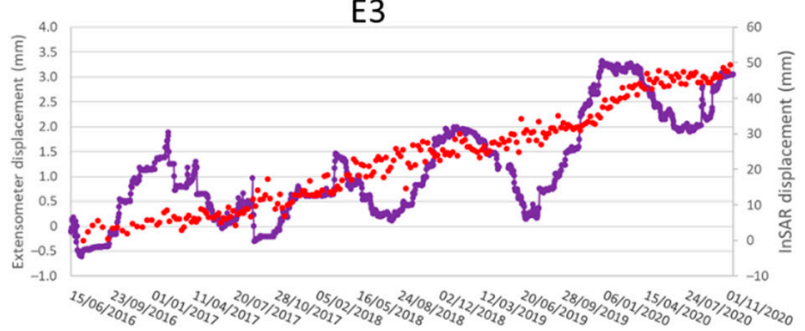

E6

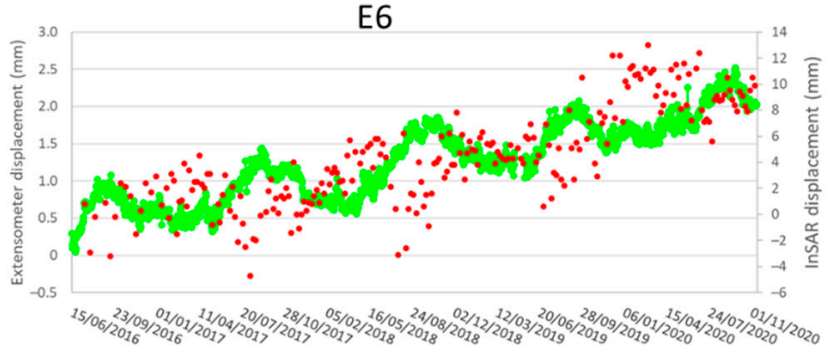

Figure 13. Four examples of comparison between deformations measured by bar extensometers (E1, E3, E4 and E6, colored lines) and PSI located close to the extensometer (red dots).

To compare the deformations recorded by the extensometers and what was measured by InSAR data, we used the inSAR descending dataset because it was the most appropriate for considering slope orientation and movement direction. By considering the different components of the displacement vectors measured by the two technologies, the comparison is mainly focused on the identification of possible correlations between the trends measured by the two datasets; rather than on a measurement of the absolute values of deformation.

For a better visual comparison with the extensometer data, the cumulative deformations measured by MT-InSAR descending data, which are conventionally negative (movement away from the sensor), have been made positive.

In general, both data show deformations that follow a linear trend and reach higher cumulative values in the western and south-western parts of the hamlet. Specifically, the area around the former school (monitored by extensometers E4 and E6) shows the greatest displacements (Figure 13), both from satellite data and from the analysis of the in situ data. In Figure 13, data acquired by E6 and E4 were compared with those acquired by the Sentinel-1 satellite in descending orbit. Additionally, in this case, displacements are characterized by an evident linear trend; these values are compatible with a downstream movement of the landslide, which is active and characterized by an average speed of a few mm/y. The correlation between PSI data and extensometer data in E6 and E4 is good, and the deformation trends are very similar, showing correlation coefficients around 0.7. A comparison between the E1 measurements and the satellite radar data, acquired in descending orbit, is shown because the E1 extensometer highlights substantial stability without remarkable deformation (Figure 13). Specifically, both the E2 extensometer and PSI data point to stability, with an evident seasonal effect. The same behavior can be observed in correspondence with the E3 extensometer. The comparison between MTInSAR and in situ data suggests that, the lower the ground deformation velocity, the higher the negative influence of seasonality on the extensometer data in the correlation coefficient; the correlation is better when comparing the extensometer with MT-InSAR descending data, at least with respect to ascending MT-InSAR data (Figure 14). PSI and extensometer 
data highlight the same acceleration periods, but the extensometer detects an acceleration a few days before MT-InSAR data.

E1

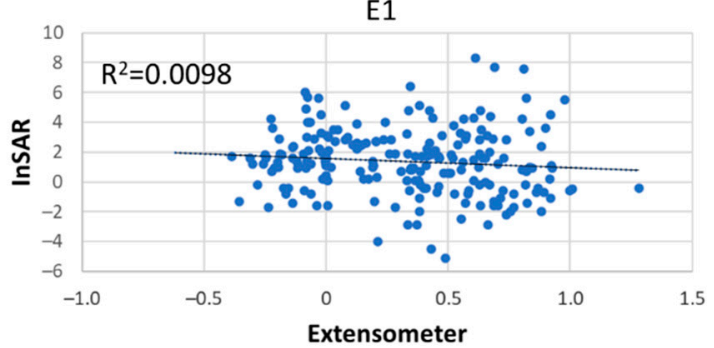

E4

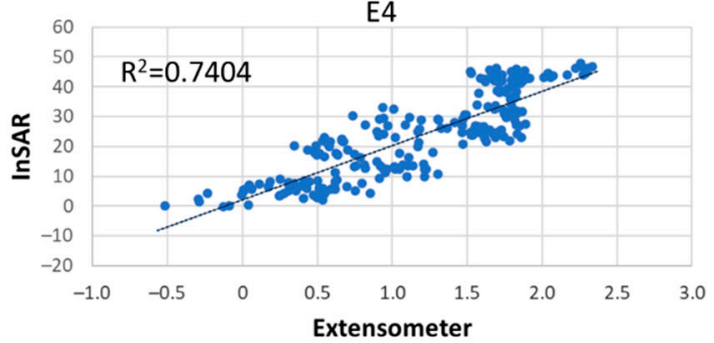

E3

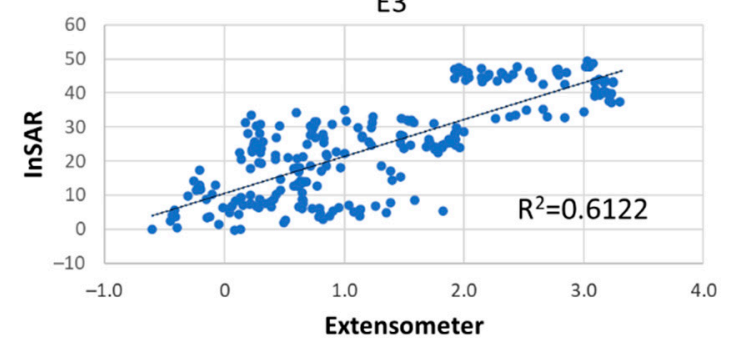

E6

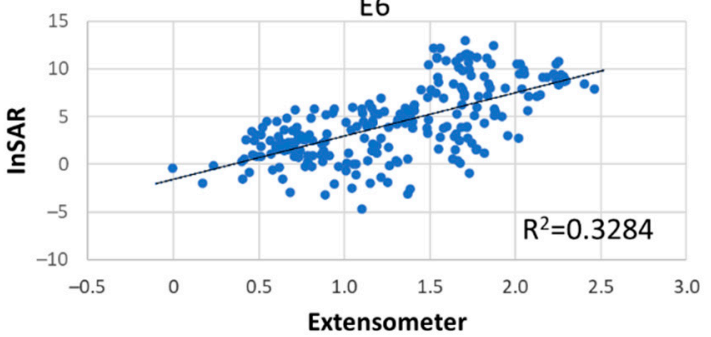

Figure 14. Correlation graphs between MT-InSAR and extensometer data for four measurement points (E1, E3, E4 and E6).

The comparison between geotechnical monitoring data and MT-InSAR data allowed us to demonstrate that the deformation trends and acceleration periods of the landslide are correctly identified by all the sensors (Figure 15). Furthermore, all the sensors belonging to the monitoring system show that the increase in deformation rate during the monitored period is triggered by long lasting and/or intense rainfall events. For example, the period of November 2019 (Figure 15) triggered an acceleration in the deformation that was clearly detected by ascending and descending MT-InSAR data, extensometer data, and inclinometer data.

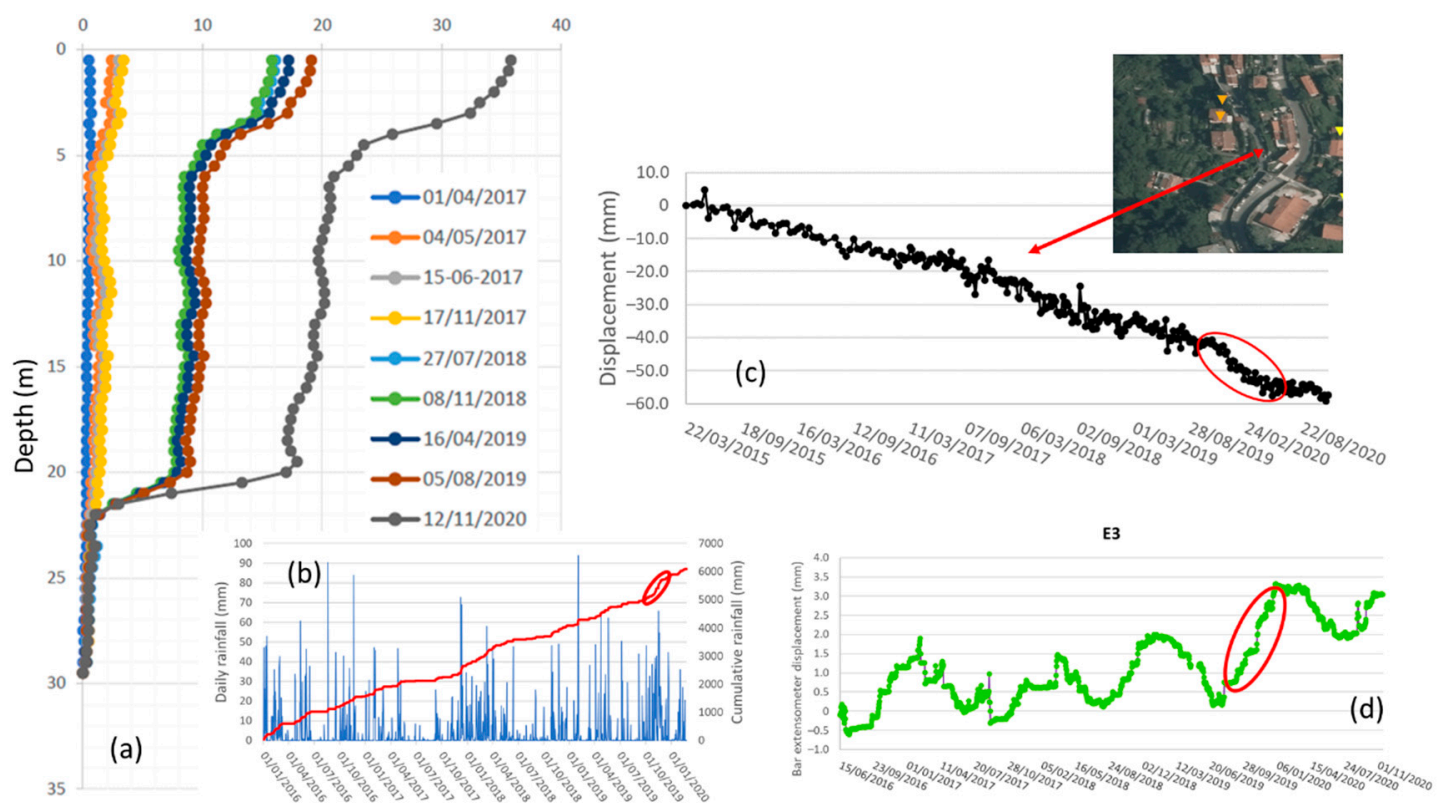

Figure 15. Example of an acceleration period between October and November 2019 and recorded by the inclinometer (a), MT-InSAR data (c), and extensometer (d), that was triggered by heavy rainfall (b). Red arrow (a) and red ellipses (b, $\mathbf{c}$ and $\mathbf{d})$ highlight the period between October and November 2019. 


\section{Conclusions}

The recent ground motion service that has been active in the Tuscany region since October 2016, and which is based on the systematic processing of Sentinel-1 images, represents a useful system for detecting and monitoring slow-moving landslides and subsidence areas. In this work, we used the MT-InSAR data of the Tuscany region monitoring system to monitor a landslide which affecting the hamlet of Pariana, Massa (Italy). Pariana is also monitored by a wireless sensor network made of geotechnical sensors. MT-InSAR and extensometer data were compared and used together to monitor the landslide and to understand how rainfall can influence the deformation rates. Results show a good agreement in both the spatial and temporal distribution of the deformations by both the monitoring systems, with a good correlation between them. The comparison between deformation data and rainfall data suggests that rainfall is responsible for the identified accelerations in the deformation rate of the landslide. These results confirm that a monitoring system based on the routine acquisition and processing of Sentinel-1 SAR images is useful for monitoring slow-moving landslides over long periods. Considering the revisiting time of Sentinel-1, the time needed for the processing of the SAR images, and the time required for the interpretation of the MT-InSAR data, a space-based monitoring system cannot be used as early warning system. The coupling between MT-InSAR data and the adopted wireless sensor network is a good compromise when considering the cost of installation and maintenance of the latter when it comes to a useful and low-cost monitoring system for slow-moving landslides that affect buildings and/or infrastructure.

Archive MT-InSAR data such as ERS 1/2, Envisat, and in this case, COSMO-SkyMed, can be used to select the optimal location for in situ sensors, especially when considering the spatial distribution of the past deformations of a slope. During the activity of the wireless sensors network, MT-InSAR data can be used to confirm measurements, and geotechnical monitoring data can be used to validate MT-InSAR data. In case of success in terms of validation, and if the landslide does not need an early warning system, MT-InSAR data can be used to monitor the evolution of deformations, even in the absence of in situ sensors. This approach can be easily adopted for most urban or semi-urban areas affected by slow-moving ground deformations.

Author Contributions: Conceptualization, supervision and review, P.F.; data analysis and writing original draft A.C.; data analysis V.T.; field data collection, M.N. and L.L.; review, R.G., F.d.P. and D.T. All authors have read and agreed to the published version of the manuscript.

Funding: This research received no external funding.

Institutional Review Board Statement: Not applicable.

Informed Consent Statement: Not applicable.

Data Availability Statement: MT-InSAR data are available at the following links: http:/ /www.pcn. minambiente.it/viewer/ (accessed on 7 January 2021) https://geoportale.lamma.rete.toscana.it/ difesa_suolo/\#/viewer/openlayers/326 (accessed on 7 January 2021).

Acknowledgments: Authors would like to thank the anonymous reviewers for improving the quality of the manuscript.

\section{References}

1. Petley, D. Global patterns of loss of life from landslides. Geology 2012, 40, 927-930. [CrossRef]

2. Herrera, G.; Mateos, R.M.; Garciá-Davalillo, J.C.; Grandjean, G.; Poyadji, E.; Maftei, R.; Filipciuc, T.-C.; Auflič, M.J.; Jež, J.; Podolszki, L.; et al. Landslide databases in the Geological Surveys of Europe. Landslides 2018, 15, 359-379. [CrossRef]

3. Codebo, L.; Delmonaco, G.; Margottini, C.; Puglisi, C.; Serafini, S. Landslide susceptibility in the Cardoso slope (Versilia-Italy) consequences of the flash flood of 19 June 1996. In Landslides in Research, Theory and Practice, Proceeding of the $8^{\text {th }}$ International Symp. on Landslides, Cardiff, UK, 26-30 June 2000; Bromhead, E., Dixon, N., Ibsen, M., Eds.; ICE Publishing: London, UK, 2000; Volume 1, pp. 293-298.

4. Montrasio, M.; Valentino, R.; Losi, G.L. Raifall-induced shallow landslides: A model for the triggering mechanism of some case studies in Northenr Italy. Landslides 2018, 6, 359-379. [CrossRef] 
5. Casagli, N.; Dapporto, S.; Ibsen, M.; Tofani, V.; Vannocci, P. Analysis of the landslide triggering mechanism during the storm of 20-21 November 2000, in Northern Tuscany. Landslides 2006, 3, 13-21. [CrossRef]

6. Rosi, A.; Segoni, S.; Catani, F.; Casagli, N. Statistical and environmental analyses for the definition of a regional rainfall threshold system for landslide triggering in Tuscany (Italy). J. Geogr. Sci. 2012, 22, 617-629. [CrossRef]

7. Cruden, D.M.; Varnes, D.J. Landslide type and processes. In Landslides: Investigation and Mitigation, Sp. Rep. 247; Turner, A.K., Schuster, R.L., Eds.; Transportation Research Board, National Research Council, National Academy Press: Washington, DC, USA, 1996; pp. 36-75.

8. Guzzetti, F. Landslide fatalities and the evaluation of landslide risk in Italy. Eng. Geol. 2000, 58, 89-107. [CrossRef]

9. Carlini, M.; Chelli, A.; Vescovi, P.; Artoni, A.; Clemenzi, L.; Tellini, C.; Torelli, L. Tectonic control on the development and distribution of large landslides in the Northern Apennines. Geomorphology 2016, 253, 425-437. [CrossRef]

10. Raspini, F.; Bianchini, S.; Ciampalini, A.; Del Soldato, M.; Montalti, R.; Solari, L.; Tofani, V.; Casagli, N. Persistent Scatterers continuous streaming for landslide monitoring and mapping: The case of the Tuscany region (Italy). Landslides 2019, 16, $2033-2044$. [CrossRef]

11. Del Soldato, M.; Solari, L.; Raspini, F.; Bianchini, S.; Ciampalini, A.; Montalti, R.; Ferretti, A.; Pellegrineschi, V.; Casagli, N. Monitoring Ground Instabilities Using SAR Satellite Data: A Practical Approach. ISPRS Int. J. Geo-Inf. 2019, 8, 307. [CrossRef]

12. Stark, T.D.; Choi, H. Slope inclinometers for landslides. Landslides 2008, 5, 339. [CrossRef]

13. Sharon, M.; Eberhardt, E. Guidelines for Slope Performance Monitoring; CRC Press, Taylor \& Francis Group: Leiden, The Netherland, 2020.

14. Li, Y.; Huang, J.; Jiang, S.-H.; Huang, F.; Chang, Z. A web-based GPS system for displacement monitoring and failure mechanism analysis of reservoir landslide. Sci. Rep. 2017, 7, 17171. [CrossRef]

15. Corominas, J.; Moya, J.; Lloret, A.; Gili, J.; Angeli, M.; Pasuto, A.; Silvano, S. Measurement of landslide displacements using a wire extensometer. Eng. Geol. 2000, 55, 149-166. [CrossRef]

16. Colesanti, C.; Ferretti, A.; Prati, C.; Rocca, F. Monitoring landslides and tectonic motions with the Permanent Scatterers Technique. Eng. Geol. 2003, 68, 3-14. [CrossRef]

17. Frodella, W.; Ciampalini, A.; Gigli, G.; Lombardi, L.; Raspini, F.; Nocentini, M.; Scardigli, C.; Casagli, N. Synergic use of satellite and ground based remote sensing methods for monitoring the San Leo rock cliff (Northern Italy). Geomorphology 2016, 264, 80-94. [CrossRef]

18. Ma, J.; Niu, X.; Liu, X.; Wang, Y.; Wen, T.; Zhang, J. Thermal Infrared Imagery Integrated with Terrestrial Laser Scanning and Particle Tracking Velocimetry for Characterization of Landslide Model Failure. Sensors 2020, 20, 219. [CrossRef]

19. Lombardi, L.; Nocentini, M.; Frodella, W.; Nolesini, T.; Bardi, F.; Intrieri, E.; Carlà, T.; Solari, L.; Dotta, G.; Ferrigno, F.; et al. The Calatabiano landslide (southern Italy): Preliminary GB-InSAR monitoring data and remote 3D mapping. Landslides 2017, 14, 685-696. [CrossRef]

20. Darvishi, M.; Schlögel, R.; Kofler, C.; Cuozzo, G.; Rutzinger, M.; Zieher, T.; Toschi, I.; Remondino, F.; Mejia-Aguilar, A.; Thiebes, B.; et al. Sentinel-1 and Ground-Based Sensors for Continuous Monitoring of the Corvara Landslide (South Tyrol, Italy). Remote Sens. 2018, 10, 1781. [CrossRef]

21. Lan, H.; Zhao, X.; Macciotta, R.; Peng, J.; Li, L.; Wu, Y.; Zhu, Y.; Liu, X.; Zhang, N.; Liu, S.; et al. The cyclic expansion and contraction characteristics of a loess slope and implications for slope stability. Sci. Rep. 2021, 11, 2250. [CrossRef] [PubMed]

22. Woods, A.; Macciotta, R.; Hendry, M.T.; Stewart, T.; Marsh, J. Updated understanding of the deformation characteristics of the Checkerboard Creek rock slope through GB-InSAR monitoring. Eng. Geol. 2021, 281, 105974. [CrossRef]

23. Fernández, T.; Pérez, J.L.; Cardenal, J.; Gómez, J.M.; Colomo, C.; Delgado, J. Analysis of Landslide Evolution Affecting Olive Groves Using UAV and Photogrammetric Techniques. Remote Sens. 2016, 8, 837. [CrossRef]

24. Rossi, G.; Tanteri, L.; Tofani, V.; Vannocci, P.; Moretti, S.; Casagli, N. Multitemporal UAV surveys for landslide mapping and characterization. Landslides 2018, 15, 1045-1052. [CrossRef]

25. Intrieri, E.; Gigli, G.; Mugnai, F.; Fanti, R.; Casagli, N. Design and implementation of a landslide early warning system. Eng. Geol. 2012, 147-148, 124-136. [CrossRef]

26. Koha, V.V.; Takayama, S. Wireless sensor network in landslide monitoring system with remote data management. Measurements 2018, 118, 214-229.

27. Jeong, S.; Ko, J.; Kim, J. The effectiveness of a wireless sensor network system for landslide monitoring. IEEE Access 2020, 8, 8073-8086. [CrossRef]

28. Singhroy, V.; Mattar, K.E.; Gray, A.L. Landslide characterisation in Canada using interferometric SAR and combined SAR and TM images. Adv. Space Res. 1998, 21, 465-476. [CrossRef]

29. Massonnet, D.; Feigl, K.L. Radar interferometry and its application to changes in the Earth's surface. Rev. Geophys. 1998, 36, 441-500. [CrossRef]

30. Farina, P.; Colombo, D.; Fumagalli, A.; Marks, F.; Moretti, S. Permanent scatterers for landslides investigations: Outcomes from the ESA-SLAM project. Eng. Geol. 2006, 88, 200-217. [CrossRef]

31. Crosetto, M.; Monserrat, O.; Cuevas-González, M.; Devanthéry, N.; Crippa, B. Persistent scatterer interferometry: A review. ISPRS J. Photogramm. Remote Sens. 2016, 115, 78-89. [CrossRef]

32. Raspini, F.; Bianchini, S.; Ciampalini, A.; Del Soldato, M.; Solari, L.; Novali, F.; Del Conte, S.; Rucci, A.; Ferretti, A.; Casagli, N. Continuous, semi-automatic monitoring of ground deformation using Sentinel-1 satellites. Sci. Rep. 2018, 8, 1-11. [CrossRef] 
33. Corominas, J.; Moya, J.; Ledesma, A.; Lloret, A.; Gili, J.A. Prediction of ground displacement and velocities from groundwater level changes at the Vallacebre landslides (Eastern Pyrenees, Spain). Landslides 2005, 2, 83-96. [CrossRef]

34. Herrera, G.; Fernández-Merodo, J.A.; Mulas, J.; Pastor, M.; Luzi, G.; Monserrat, O.A. Landslide forecasting model using ground based SAR data: The Portalet case study. Eng. Geol. 2009, 105, 220-230. [CrossRef]

35. Troncone, A.; Pugliese, L.; Lamanna, G.; Conte, E. Prediction of rainfall-induced landslide movements in the presence of stabilizing piles. Eng. Geol. 2021, 288, 106143. [CrossRef]

36. Peel, M.C.; Finlayson, B.L.; Mcmahon, T.A. Updated world map of the Köppen-Geiger climate classification. Hydrol. Earth Syst. Sci. 2007, 11, 1633-1644. [CrossRef]

37. Elter, P. Introduction a la geologie de l'Apennin septentrional. Bull. Soc. Geol. Fr. 1975, 7, 956-962. [CrossRef]

38. Carmignani, L.; Klingfield, R. Crustal extension in the Northern Apennines: The transition from compression to extension in the Alpi Apuane core complex. Tectonics 1990, 9, 1275-1303. [CrossRef]

39. Molli, G.; Conti, P.; Giorgetti, G.; Meccheri, M.; Oesterling, N. Microfabric studies on the deformational and thermal history of the Alpi Apuane marbles (Carrara marbles), Italy. J. Struct. Geol. 1990, 22, 1809-1825. [CrossRef]

40. Cerrina Feroni, A.; Plesi, G.; Fanelli, G.; Leoni, L.; Martinelli, P. Contributo alla conoscenza dei processi metamorfici di grado molto basso (anchimetamorfismo) a carico della falda toscana nell'area del ricoprimento apuano. Boll. Soc. Geol. It. 1983, 102, 269-280.

41. Tosatti, G.; Castaldini, D.; Barbieri, M.; D’Amato Avanzi, G.; Giannecchino, R.; Mandrone, G.; Pellegrini, M.; Perego, S.; Puccinelli, A.; Romeo, R.W.; et al. Additional causes of seismically-related landslides in the Northern Apennines, Italy. Rev. Geomorf. 2008, $10,5-21$.

42. Ferretti, A.; Prati, C.; Rocca, F. Permanent scatterers in SAR interferometry. IEEE Trans. Geosci. Remote Sens. 2001, 39, 8-20. [CrossRef]

43. Ferretti, A.; Prati, C.; Rocca, F. Nonlinear subsidence rate estimation using permanent scatterers in dfferential SAR interferometry. IEEE Trans. Geosci. Remote Sens. 2000, 38, 2202-2212. [CrossRef]

44. Ciampalini, A.; Solari, L.; Giannecchini, R.; Galanti, Y. Evaluation of subsidence induced by long-lasting buildings load using InSAR technique and geotechnical data: The case study of a freight terminal (Tuscany, Italy). Int. J. App. Earth Observ. Geoinf. 2019, 82, 101925. [CrossRef]

45. Jones, C.E.; An, K.; Blom, R.G.; Kent, J.D.; Ivins, E.R.; Bekaert, D. Anthropogenic and geologic influences on subsidence in the vicinity of New Orleans, Louisiana. J. Geophys. Res. Solid Earth 2016, 121, 3867-3887. [CrossRef]

46. Ferretti, A.; Fumagalli, A.; Novali, F.; Prati, C.; Rocca, F.; Rucci, A. A new algorithm for processing interferometric data-stacks: SqueeSAR. IEEE Trans. Geosci. Remote Sens. 2001, 49, 3460-3470. [CrossRef]

47. Costantini, M.; Ferretti, F.; Minati, F.; Falco, S.; Trillo, F.; Colombo, D.; Novali, F.; Malvarosa, F.; Mammone, C.; Vecchioli, F.; et al. Analysis of surface deformation over the whole Italian territory by interferometric processing of ERS, Envisat and COSMOSkyMed radar data. Remote Sens. Environ. 2017, 202, 250-275. [CrossRef]

48. Mucchi, L.; Jayousi, S.; Martinelli, A.; Caputo, S.; Intrieri, E.; Gigli, G.; Gracchi, T.; Mugnai, F.; Favalli, M.; Fornaciai, A.; et al. A Flexible Wireless Sensor Network Based on Ultra-Wide Band Technology for Ground Instability Monitoring. Sensors 2018, $18,2948$.

49. Madson, A.; Fielding, E.; Sheng, Y.; Cavanaugh, K. High-resolution spaceborne, airborne and in-situ landslide kinematic measurements of the Slumgullion landslide in Southwest Colorado. Remote Sens. 2019, 11, 265. [CrossRef]

50. Vassallo, R.; Calcaterra, S.; D’Agostino, N.; De Rosa, J.; Di Maio, C.; Gambino, P. Long-Term Displacement Monitoring of Slow Earthflows by Inclinometers and GPS, and Wide Area Surveillance by COSMO-SkyMed Data. Geosciences 2020, 10, 171. [CrossRef] 